\title{
Bandas de Constrição Congênitas
}

\author{
Congenital Constriction Bands
}

Arlindo G. Pardini JR ${ }^{1}$., Marcos Antônio dos Santos ${ }^{2}$, Afrânio D. Freitas ${ }^{3}$

\section{RESUMO}

A síndrome da banda de constrição congênita é uma patologia rara, de ocorrência ocasional na natureza e não existe predisposição genética. É freqüentemente associada a amputações de dedos ou membros, sindactilia, acrossindactilia (sindactilia fenestrada), mal formações em face, tórax e/ou abdômen.

O presente trabalho representa nossa experiência na abordagem e tratamento da Síndrome da Banda de Constrição Congênita. Foram tratados 10 pacientes atendidos em nosso serviço em um período de 20 anos.

Descritores: Defeito Congênito, Mão, Bandas de Constrição.

\section{INTRODUÇÃO}

A síndrome da banda de constrição congênita é uma patologia incomum e etiologia ainda controversa. 1,3,5,6,7,9,10,11 Possui uma variada gama de apresentação clínica, as quais variam de simples anel de constrição em dedos e artelhos, podendo estar presente amputações, sindactilia e/ou acrossindactilia (sindactilia fenestrada) a má formações associadas de face, cabeça e tronco como lábio leporino, anencafalia, encefalocele, hidrocefalia, microftalmia, toracoesquise, coração extratorácico e gastroesquise. 1,3,4,5,6,8,10

A síndrome da banda de constrição é citada na literatura por vários sinônimos como: anel de constrição congênito, banda de constrição anular, complexo de A.D.A.M. (deformidade amniótica, aderências, mutilações), complexo da ruptura da banda amniótica, displasia de Streeter, defeito anular congênito e síndrome da banda amniótica ${ }^{1,2,10}$

Há consenso em afirmar que trata-se de uma patologia de origem

\section{SUMMARY}

Congenital Constriction Band Syndrome is a rare pathology, of occasional occurrence in the nature and genetic predisposition doesn't exist. It is frequently associated with amputations of fingers or members, sindactily, acrossindactily (fenestrated sindactily), malformations in face, thorax, and/or abdomen.

The present work represents our experience in the evaluation and treatment of the Constriction Congenital Band Syndrome. We have treated and assisted 10 patients in our service in a 20 year-old period.

Key Words: Congenital Defect, Hand, Constriction Band.

\section{INTRODUCTION}

The congenital constriction band syndrome is an unusual pathological condition and its etiology is still controverse. $1,3,5,6,7,9,10,11$ Clinical presentation is varied, from simple constriction rings in fingers and toes present in amputations, syndactyly and/or acrosyndactyly (fenestrated syndactyly) to associated malformations of the face, head and trunk, as cleft lip, anencephalia, encephalocele, hidrocephalus, microphtalmia, thoracoschisis, extrathoracic heart and gastroschisis. ${ }^{1,3,4,5,6,8,10}$

The constriction band syndrome has a number of synonyms in the literature as: congenital constriction ring, annular constriction band, A.D.A.M. (amniotic deformity, adherences, mutilations) complex, amniotic band rupture complex, Streeter dysplasia, congenital annular defect and amniotic band syndrome.1,2,10

There is consensus concerning the fact that it is a non-genetic
Trabalho realizado no Hospital Ortopédico - AMR - Rua Professor Otávio Coelho de Magalhães, 111 - Belo Horizonte - MG - CEP 30210-300

1 - Chefe do Serviço de Cirurgia da Mão do Hospital Ortopédico, AMR

2 - Ex-residente do Serviço de Cirurgia da Mão do Hospital Ortopédico, AMR

3 - Cirurgião de Mão dos Hospitais, Ortopédico - AMR, Belo Horizonte e Maria Amélia Lins (FHEMIG)
This study was carried out in: Hospital Ortopédico - AMR - Rua Prof. Otávio Coelho de Magalhães, 111 - Belo Horizonte - MG - CEP 30210-300

1 - Head, Hand Surgery Service, Hospital Ortopédico, AMR

2 - Resident, Hand Surgery Service, Hospital Ortopédico, AMR

3 - Hand Surgeon, Hospital Ortopédico, AMR, Belo Horizonte; Hospital Maria Amélia Lins (FHEMIG). 
não genética, de ocorrência ocasional na natureza, 3,5,6,10,11 na qual o acometimento assimétrico de membros é regra, não havendo, portanto, lesões iguais em indivíduos diferentes, sequer lesão simétrica em um mesmo indivíduo. ${ }^{8,10,11} \mathrm{~A}$ incidência da referida síndrome é apresentada em literatura recente como sendo

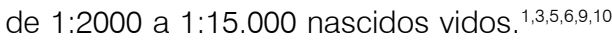
Acomete igualmente crianças do sexo masculino e feminino ${ }^{5,10}$ e não existe predileção por qualquer grupo étnico. ${ }^{3}$ Nas crianças nascidas com alterações causadas por banda de constrição congênita, alguns autores relatam alta incidência de prematuridade e baixo peso ao nascimento. ${ }^{1,10}$

Várias teorias foram sugeridas na tentativa de explicar a etiopatogenia das bandas amnióticas, sendo mais aceitas as teorias intrínseca e extrínseca. Streeter propôs, como teoria intrínseca, que a síndrome da banda de constrição congênita representaria um defeito inerente ao desenvolvimento embriogênico. As bandas de constrição seriam resultado de um defeito na diferenciação do plasma germinativo o qual formaria as bandas fibróticas e tornaria o membro necrótico. 1,2,3,5,9,10,11 Torpin defendeu, como teoria extrínseca, que a ruptura do âmniom formaria fios de tecido amniótico que enlaçaria os membros do feto e causaria as bandas de constrição; e tendo em vista que a taxa de crescimento do feto é maior que a do referido tecido, constrições, estrangulamentos, necrose e amputações ocorreriam. ${ }^{1,2,3,4,5,9,10,11}$ Ainda em apoio à teoria extrínseca, tem-se postulado que a época da gravidez que ocorre a ruptura amniótica seria responsável pela maior ou menor gravidade das lesões. Rupturas precoces causariam lesões graves no feto como lesões em cabeça e tronco e freqüentemente seriam a causa de aborto ou natimorto e rupturas amnióticas mais tardias resultariam primariamente em envolvimento dos membros. . $^{3,10}$ Uma das causas de ruptura de âmniom durante a gravidez, também apoiando a teoria extrínseca, tem sido atribuído ao oligodrâmnio temporário. 1,3,4,10,11

É achado freqüente, ao nascimento, associação de áreas de estrangulamento por bandas de constrição, coto de amputações, sindactilia, acrossindactilia e hipoplasia de dedos e artelhos. 2,8,10,11 Nos membros superiores, as regiões distais são mais afetadas, principalmente os dedos centrais (II, III e IV) e nos membros inferiores o Hálux e segundo artelho são os mais afetados. ${ }^{1,5,10,11}$ O polegar raramente é afetado, tendo sido

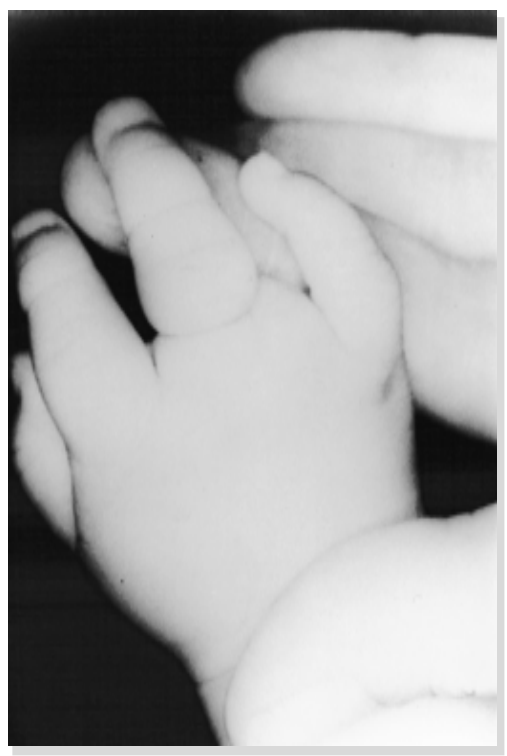

Fig. 1 - Anéis de constrição acometendo II, III e IV dedos com amputação congênita do $\mathrm{IV} \mathrm{e}$ hipoplasia associada.

pathology, occurring occasionally in the nature, 3,5,6,10,11 and that limb assymetric involvement is a rule; no similar lesions are seen in different individuals, and symmetric lesions do not occur in the same individual. 8,10,11 Incidence was mentioned in recently published papers as 1:2000 to 1:15000 live births. ${ }^{1,3,5,6,9,10}$ Male and female children ${ }^{5,10}$ and all ethnic groups ${ }^{3}$ are equally affected. Among the children born with alterations caused by the congenital constriction band some authors observed high incidence of prematures and low weighted newborns. ${ }^{1,10}$

Several theories were put forward to explain the amniotic bands etiopathogeny, and the most accepted are the intrinsic and the intrinsic theories. Streeter proposed an intrinsic theory defending that the congenital constriction band would represent an inherent defect of the embryogenic development. The constriction bands would be the result of a defect in the differentiation of the germinative plasma, which would form fibrotic bands and cause necrosis. 1,2,3,5,9,10,11 Torpin defended an extrinsic theory: rupture of the amnion forms threads of amniotic tissue which intertwine with the fetus limbs causing constriction bands; considering that the fetus growth is quicker than the tissue, constriction, strangling, necrosis and amputation would occur 1,2,3,4,5,9,10,11 Also supporting the intrinsic theory, it has been postulated that the moment during pregnancy when amniotic rupture occurs accounts for more or less severe lesions.

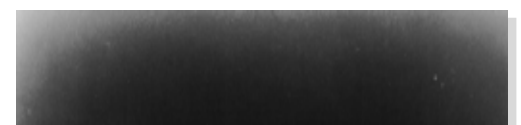
Early ruptures would cause severe lesions in the fetus head, trunk and frequently would be the cause of abortion or stillbirths and amniotic ruptures; later ruptures would primarily result in involvement of the limbs. 3,10 One of the causes of amnion rupture during pregnancy, also supporting the intrinsic theory, has been considered the temporary oligodramnion. 1,3,4,10,11

It is common to observe at birth the association of areas strangled by constriction bands, stumps, syndactyly, acrosyndactyly and hypoplasia of fingers and toes 2,8,10,11 In the upper limbs, the distal regions are more affected, mainly the central fingers (II, III e IV) and in the lower limbs the hallux and the second toe are the most affected. ${ }^{1,5,10,11}$ The thumb is rarely affected, since it is protected by the palm during pregnancy. ${ }^{1}$ In syndactyly and acrosyndactyly caused by constriction bands, bone fusion is rarely observed, 
atribuído esta característica ao fato do mesmo permanecer protegido na palma da mão durante a gravidez. ${ }^{1} \mathrm{Na}$ sindactilia e acrossindactilia causadas por bandas de constrição, raramente é observado fusão óssea, ocorrendo apenas fusão de partes moles. ${ }^{10,11}$

As bandas fibrosas podem ser superficiais ou profundas e podem circular total ou parcialmente um membro ou dedos afetados. Bandas superficiais normalmente não causam danos neurovasculares ou dificuldade em retorno linfático, evitando assim o linfedema. Bandas profundas, no entanto, podem causar danos neurovasculares de diversos graus, evoluindo, por vezes, para uma liberação cirúrgica de urgência, devido aumento progressivo do edema distal à área de compressão com comprometimento vascular. ${ }^{1,8,9,10,11}$ Lesão de nervo periférico devido a bandas de constrição profunda (geralmente proximal ao punho), tem sido descrito na literatura, sendo classificadas como axoniotmese e neurotmese. O segmento de nervo lesado é o tecido nervoso sob a banda fibrosa. O tecido nervoso proximal e distal à banda de constrição apresenta-se com aspecto macroscópico normal. 7,10

O diagnóstico precoce da síndrome da banda de constrição congênita pode ser feito através da ultra-sonografia no final do primeiro trimestre de gestação. 3,6,10

O tratamento, nos casos que há necessidade de intervenção cirúrgica, é feito através de zetaplastia, dablioplastia 1,5,8,9,10,11 ou ressecção do anel fibroso com rotação de retalho de gordura subcutânea e fechamento da pele. ${ }^{8,11} \mathrm{O}$ procedimento pode ser feito em um só tempo cirúrgico ${ }^{5,9}$ ou como recomenda a maioria dos autores, libera-se metade da circunferência do anel de constrição em um tempo e a outra metade em um segundo tempo ${ }^{1,8,10,11}$ seis a doze semanas após o primeiro procedimento cirúrgico. ${ }^{11}$

\section{CASUÍSTICA E MÉTODOS}

Nossa série é constituída do estudo e análise de dez pacientes tratados no Serviço de Cirurgia da Mão do Hospital Ortopédico no período de 1979 a 1999 (20 anos) e representa nossa experiência na abordagem e terapêutica da Síndrome da Banda de Constrição Congênita.

Dos pacientes analisados três eram do sexo

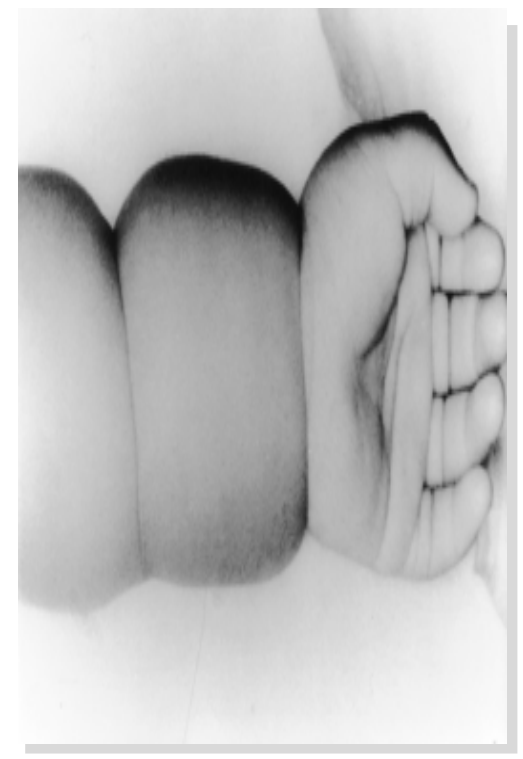

Fig. 3 - Anéis de constrição a nível da prega do punho e terço médio do antebraço. occurring only fusion in the soft parts. ${ }^{10,11}$

The fibrous bands can be superficial or deep and may totally or partially embrace an affected limb or finger. Superficial bands normally do not cause neurovascular damage or difficulty to lymphatic return, avoiding lymphedema. Deep bands, on the other hand, can cause neurovascular damage of variable intensity, demanding at times urgent surgical intervention due to intensification of the progressive distal edema in the compression area which presents vascular involvement. 1,8,9,10,11 Peripheral nerve lesions due to deep constriction bands (in general proximal to the wrist), have been reported in the literature and are classified as axonotmesis and neurotmesis. The segment of the lesioned nerve is the nervous tissue under the fibrous band. The nervous tissue proximal and distal to the constriction band presents normal macroscopic aspect. ${ }^{7,10}$

Early diagnosis of the congenital constriction band syndrome can be made using ultrasound after the first three months of pregnancy. 3,6,10

Treatment, in the cases when surgical intervention is necessary, is made using Zplasty, Wplasty 1,5,8,9,10,11 or ressection of the fibrous ring with flap rotation of the subcutaneous fat and closure of the skin. ${ }^{8,11}$ All the procedure can be carried out in a single surgical intervention ${ }^{5,9}$ or, as most authors recommend, half of the circumference is liberated from the constriction ring in one occasion and the other half in a second occasion 1,8,10,11 six to twelve weeks after the first intervention. ${ }^{11}$

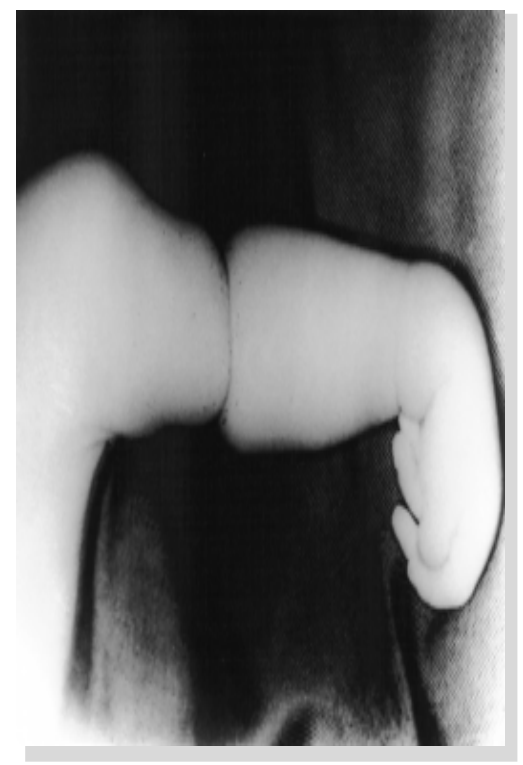

Fig. 4 - Anel de constrição a nível do terço distal do braço e punho em flexão devido lesão do nervo radial. Mesmo paciente da fig. 11.

\section{MATERIAL AND METHODS}

Ten patients studied and analyzed in the Hand Surgery Service, Hospital Ortopédico, from 1979 to 1999 (twenty years) represent our experience in approaching and treating the Congenital Constriction Band Syndrome.

Three patients were females (30\%) and seven were males (70\%). The localization of the constriction bands was more frequent in 
feminino (30\%) e sete do sexo masculino (70\%). A localização da banda de constrição foi mais freqüente nos seguimentos distais dos membros, principalmente II, III e IV dedos, acometendo ainda mão (a nível de metacarpo), um caso, antebraço, dois casos e braço, um caso (Figs. 1,2,3,4). Encontramos incidência bilateral em quatro pacientes (40\%), três em membro direito (30\%) e três em membro esquerdo (30\%). Houve acometimento do polegar em um paciente (Fig. 5). O envolvimento de membros inferiores foi observado em dois pacientes (20\%) (Fig. 6).

Não houve relato de consangüinidade entre os pais de qualquer criança. Parto normal à termo foi regra para sete crianças $(70 \%)$, sendo somente uma nascida de parto cesáreo (à termo) e uma prematura nascida de parto normal. Uma criança era adotiva e não dispusemos de dados quanto ao parto ou gestação. O tempo médio de gestação foi de 41 semanas, variando de 36 a 42 semanas. Não houve história de ingestão acidental ou proposital de medicamentos durante a gravidez, exceto medicações de uso corrente durante a gestação e prescrita por obstetra. Houve relato de uma paciente que fez radiografia de membro inferior no final do primeiro trimestre de gestação.

As deformidades associadas à Síndrome da Banda de Constrição Congênita foram amputação de dedos: seis casos (Figs. 1,2,7,8); sindactilia, cinco casos (Fig. 9); sinostose radio-ulnar, um caso; braquissindactilia, um caso (Fig. 1); polegar trifalângico, um caso e gigantismo em dedo da mão, um caso.

Como patologia associada à banda de constrição, encontramos comunicação interventricular (C.I.V.), um caso e paralisia de nervo radial, um caso (Fig. 4).

Quanto ao grupo étnico dos pacientes, nove eram brancos (90\%) e um negro (10\%).

O tempo médio entre o nascimento e cirurgia para correção dos anéis constritivos, nos casos em que houve necessidade de correção cirúrgica, foram de 9,1 meses, sendo o mais precoce operado com 2 meses e o mais tardio com 23 meses. Um paciente não necessitou de qualquer procedimento cirúrgico e dois foram submetidos a procedimentos cirúrgicos outros que não para liberação de anel de constrição. Procedimentos outros foram efetuados para correção de sindactilia em 5 pacientes.

O tratamento cirúrgico para liberação dos anéis de constrição foi baseado no alongamento da pele e subcutâneo através da zetaplastia (plastia em "Z" das bandas fibrosas) (Fig. 10).

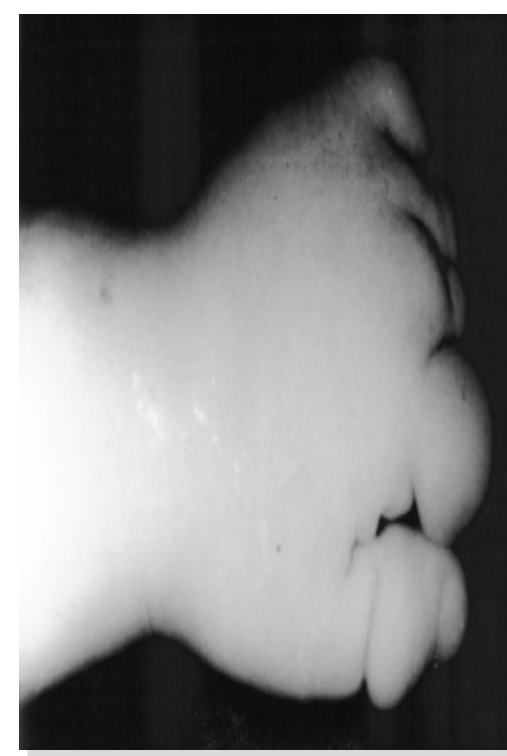

Fig. 5 - Anéis de constrição acometendo polegar

the distal segments of the limbs, mainly fingers II, III and IV, involving also the hand (at the metacarpus), one case, the forearm, two cases, and the arm, one case (Figs. $1,2,3,4)$. We detected bilateral incidence in four patients (40\%), three in the right limb (30\%), and three in the left limb (30\%). Involvement of the thumb was observed in one patient (Fig. 5). Involvement of the lower limbs was observed in two patients (20\%) (Fig. 6).

No consanguinity was present among the parents. Normal to term delivery was the rule for seven children (70\%); only one (to term) Cesarian section and one normal premature delivery. One of the children was adopted and no data about delivery or gestation were available. Mean gestation time was 41 weeks, from 36 to 42 weeks. No accidental or deliberate intake of drugs during pregnancy was reported, except drugs currently administered during gestation prescribed by the obstetrician. One mother reportedly had a lower limb X-ray at the end of the third month of pregnancy.

Deformities associated to the Congenital Constriction Band Syndrome were amputation of fingers, six cases (Figs. 1,2,7,8); syndactyly, five cases (Fig. 9); radio-ulnar synostosis, one case; brachisyndactyly, one case (Fig. 1); triphalangeal thumb, one case; and gigantism in one finger, one case.

The pathologies associated to the constriction band were interventricular communication (C.I.V.), one case; and radial nerve paralysis, one case (Fig. 4)

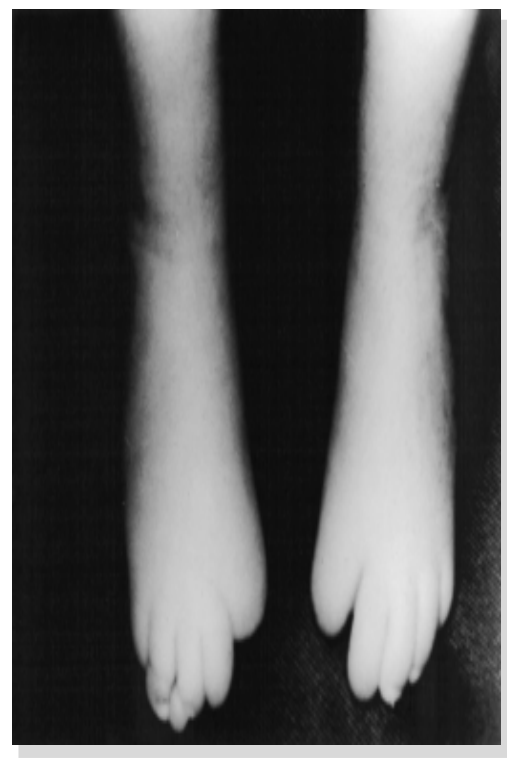

Fig. 6 - Anéis de constrição acometendo artelhos com amputação congênita do Hálux direito e esquerdo.
Nine patients were white (90\%) and one black (10\%).

Average time from birth to corrective surgery, in the cases when surgical correction of the constricting rings was necessary, was 9.1 months, the earliest case 2 months and the latest 23 months after birth. Surgery was not necessary in one patient, and two were submmitted to surgical procedures other than to liberate the constricting ring. In five patients, other procedures were effected to correct syndactyly.

Surgical treatment to liberate constriction rings was based on stretching the skin and subcutaneous Zplasty (formation in " $Z$ " of the fibrous bands) (Fig. 10).

The indication for surgical treatment was obtained following standards based on the clinical assessment of the patients (Table I). Usually, there were not alterations proximal to the constriction band. Alterations were present under the constriction ring (one case of deep 
A indicação do tratamento cirúrgico foi feita seguindo uma padronização baseada na avaliação clínica dos pacientes ( Quadro I). Via de regra não havia alteração proximal à banda de constrição. As alterações estavam presentes sob o anel de constrição ( um caso de banda de constrição profunda e circular com lesão de nervo radial) e distais a ele (Fig. 4). Nos casos de anéis de constrição superficiais ou profundos (completos ou incompletos) sem linfedema ou alterações neurovasculares, foi optado pelo tratamento conservador com avaliações periódicas do paciente. Na presença de anéis de constrição superficiais ou profundos (completos ou incompletos), mas com lesão neurovascular e/ou linfedema progressivo fizemos indicação de tratamento cirúrgico.

A abordagem cirúrgica foi feita através da liberação de metade dorsal da circunferência da banda de constrição nos casos completos, sendo indicada liberação da metade volar restante 12 semanas após o primeiro procedimento cirúrgico. and circular constriction band with radial nerve lesion) and distal to it (Fig. 4). In the cases of superficial or deep constriction rings (complete or incomplete) without lymphedema or neurovascular alterations, the conservative treatment was chosen with periodic evaluations. In cases of superficial or deep constriction rings (complete or incomplete) with neurovascular lesion and/or progressive lymphedema, surgical treatment was indicated.

Surgical approach was effected through liberation of the dorsal half of the constriction band circumference in the complete cases, and liberation of the volar half was carried out 12 weeks after the first surgery.

\section{QUADRO I - CHART I}

In dicaçẫo do Tratamento / Indication for Treatment

\begin{tabular}{|l|l|l|l|l|l||}
\hline \hline \multicolumn{5}{|c||}{ Banda de Constrição/Constriction Band } \\
\hline \hline \multicolumn{3}{|c|}{ Sup erficial/ Suerficial } & \multicolumn{3}{c||}{ Profunda / Dee } \\
\hline \hline & s/linfed. & linfedema * & & s/linfed. & linfedema * \\
\hline incompleta & observar & cirurgia & Incompleta & Observar & cirurgia \\
\hline \hline
\end{tabular}

* Linfedema elou alteraçốes neurovasculares / Lymphedema and/or neurovascubr akerations

\section{RESULTADOS}

O objetivo deste trabalho é mostrar nossa experiência na abordagem inicial, avaliação e tratamento desta patologia rara e que, por vezes, nos surpreende no consultório acompanhada de pais aflitos e preocupados com as deformidades que podem estar presentes e a possibilidade de ocorrer novamente em próxima gestação.

A história clínica sobre a gestação, parto, consangüinidade, uso de medicamentos ou intercorrências durante a gravidez foi minuciosamente investigada.

Encontramos uma discreta predominância de crianças do sexo masculino em relação ao sexo feminino na proporção aproximada de 2:1. Crianças de cor branca também foi o achado mais comum, ( nove crianças de cor branca e uma de cor negra).

A associação de bandas de constrição com sindactilia é muito freqüente e o tratamento desta pode ser postergado para uma idade mais

\section{RESULTS}

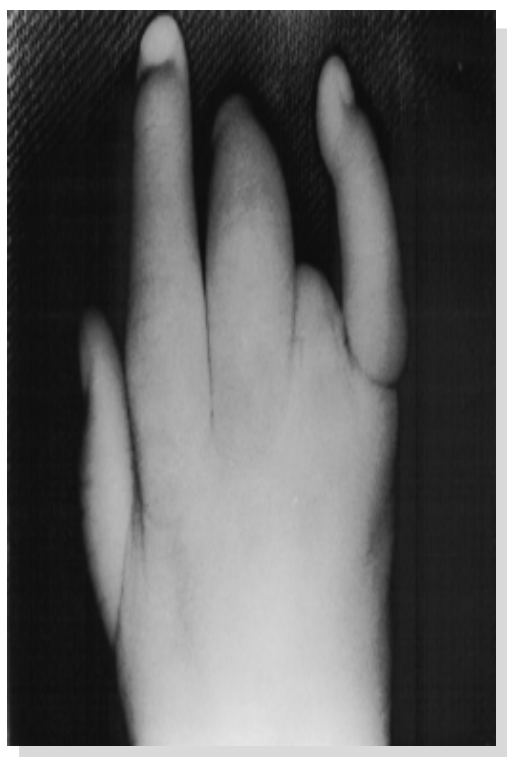

Fig. 7 - Anéis de constrição acometendo $V$ dedo com amputação congênita do IV.
The aim of this study was to point out our experience in approaching, assessing and treating this rare condition which overtakes the doctors in their practice accompanied by aflicted and worried parents due to the deformities which are present and the possibility that they occur again in a future pregnancy.

Clinical history of pregnancy, delivery, consanguinity, use of drugs or incidents during pregnancy were minutely investigated.

We found a discreet predominance (2:1) of male children. White children were also more commonly seen (nine white and one black).

The association of constriction bands with syndactyly is very frequent and the treatment of this condition can be postponed until a more adequate age, about one year.

We made an inventory of all lesions present as well as of the associated conditions, 
adequada, ao redor de um ano de idade.

Fizemos um inventário de todas lesões presentes, bem como patologias associadas, tecendo um roteiro de tratamento. A prioridade foi dada à liberação de anéis constritivos que coexistia com lesão nervosa, vascular ou linfedema progressivo, sendo uma criança operada aos dois meses de nascida devido a lesão de nervo radial (Fig. 4). Foi observado per operatoriamente que a lesão do nervo estava restrita ao tecido imediatamente abaixo da constrição e a despeito da neurectomia segmentar seguida de neurorrafia sob uso de lupa de magnificação, não foi obtido êxito, tendo sido realizado a posteriori transferências tendinosas (Fig. 11).

Optamos por liberação do anéis de constrição em dois tempos, com intervalo de 12 semanas entre cada procedimento cirúrgico e não tivemos qualquer complicação neurovascular pós operatória precoce ou tardia.

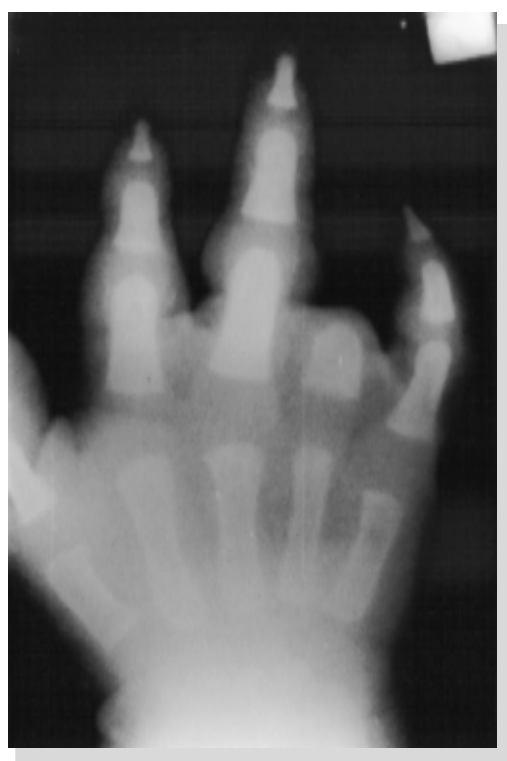

scheduling the treatment. Priority was given to liberation of the constriction rings coexistent with nervous, vascular lesions or progressive lymphedema; one child was operated on when two-month old due to lesion in the radial nerve (Fig. 4). Preoperatively we observed that this lesion was restricted to the tissue immediately below the constriction and in spite of the segmental neurectomy followed by neurorraphy under a magnifying glass, we did not succeed and, a posteriori, tendinous transferences were effected (Fig. 11).

Our option was liberation of the constriction rings in two separate interventions with a 12-week interval and no early or late post-operative neurovascular complications were observed.
Fig. 8 - Radiografia mostrando aumento de volume a nível de falange proximal do III dedo e amputação do IV dedo. Mesmo paciente da fig. 2.

\section{DISCUSSÃO}

A Síndrome da Banda de Constrição Congênita é uma patologia rara e sua etiologia ainda não foi totalmente definida. ${ }^{1,3,5,6,7,9,10,11} \mathrm{~A}$ apresentação clínica é extremamente variada, havendo casos de lesões associadas de face, tórax e/ou abdômen. 1,3,4,5,6,8,10 É freqüente associação desta patologia com amputações de dedos, sindactilia, acrossindactilia e acometimento de membros inferiores. $2,8,10,11$

Concordamos com diversos autores, que a patologia em questão não tem componente genético e sua incidência é de ocorrência esporádica na natureza. . $3,5,6,10,11$

A despeito de relatos na literatura, que a incidência seria igual em ambos sexos ${ }^{5,10} \mathrm{e}$ não haveria preferência por qualquer grupo étnico, ${ }^{3}$ encontramos uma ocorrência maior em crianças do sexo masculino e brancas.

Em nossa série, as deformidades associadas encontradas com maior freqüência foram amputações de dedos, principalmente II, III e IV, e sindactilia. O polegar foi afetado em apenas um paciente estudado. Estes achados encontram respaldo na literatura. 1,5,10,11

Concordamos ser de fundamental importância a avaliação e classificação dos anéis de constrição quanto ao envolvimento total ou parcial do membro e se há ou não acometimento de planos profundos. Este procedimento permite avaliar a presença de dano neurovascular e por conseguinte

\section{DISCUSSION}

The Congenital Constriction Band Syndrome is a rare condition and its etiology is not completely defined. 1,3,5,6,7,9,10,11 The clinical presentation is extremely varied, with cases of face, thorax and/or abdomen associated lesions. 1,3,4,5,6,8,10 Frequently, this condition is associated to the amputation of fingers, syndactyly, acrosyndactyly and lower limb involvement. 2,8,10,11

We agree with several authors that this condition lacks a genetic component and that it occurs sporadically. 3,5,6,10,11

Although the literature states that the incidence is equal in males and females ${ }^{5,10}$ and in all ethnic groups, ${ }^{3}$ we found a higher occurrence in male and white children.

In our series of patients, the most frequently found associated deformities were amputations, mainly of the II, III and IV fingers, and syndactyly. The thumb was affected in only one patient. These findings are consistent with those in the literature. 1,5,10,11

We agree that evaluation and classification of the constriction rings concerning the total or partial involvement of the limb, and whether there is involvement of deep planes, are matters of fundamental importance. This procedure permits to evaluate the presence of neurovascular injury and consequently distal involvement and the need of surgical intervention 1,8,9,10,11 The nerve lesion found in our patient was neurotmesis, consistent with the literature which mentions these lesions as 
sofrimento distal a constrição e necessidade de intervenção cirúrgica. ${ }^{1,8,9,10,11}$ A lesão de nervo encontrada em nosso paciente era neurotmese, estando em acordo com a literatura que cita serem estas lesões, via de regra, neurotmese e axoniotmese. ${ }^{7,10}$

Embora citado como eficaz, ${ }^{3,6,10}$ não temos experiência na utilização da ultra-sonografia para diagnóstico pré-natal da Síndrome da Banda de Constrição Congênita.

O tratamento cirúrgico, nos casos que se fez necessário, foi realizado através de zetaplastia. Não temos experiência com dablioplastia ou ressecção do anel fibroso com rotação de retalho de gordura subcutânea conforme é descrito por alguns autores. 1,5,8,10,11 Não aconselhamos a liberação de todo anel fibroso em um único tempo cirúrgico como alguns defendem, ${ }^{5,9}$ mas sim liberar a metade dorsal do anel de constrição em um tempo cirúrgico, a fim de melhorar a drenagem venosa e linfática, e outra metade 12 semanas mais tarde. Este procedimento também encontra defensores na literatura. ${ }^{1,8,10,11}$

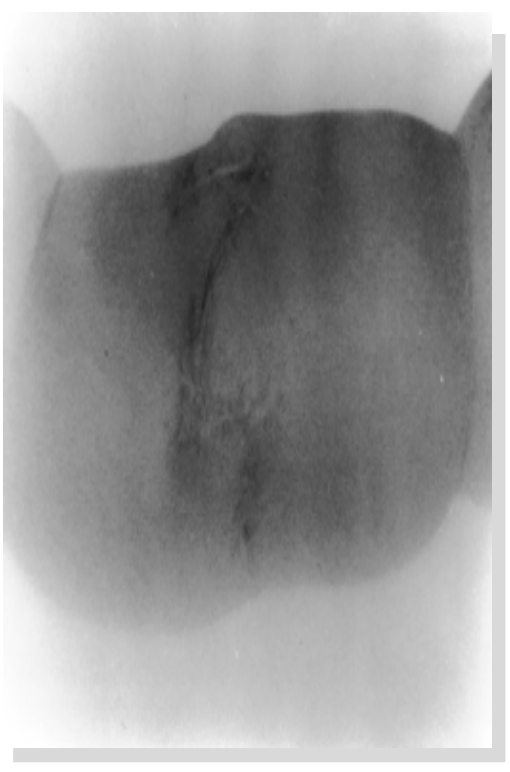

neurotmesis and axonotmesis. 7,10

Though considered effective, ${ }^{3,6,10}$ we do not have experience with ultrasound to prenatally diagnose the Congenital Constriction Band Syndrome.

Surgical treatment, when necessary, was effected using Zplasty. We did not experience Wplasty or ressection of the fibrous ring with flap rotation of subcutaneous fat as some authors describe 1,5,8,10,11 We do not agree in liberating all fibrous ring in a single surgical procedure as some preconize,,$^{5,9}$ but instead in liberating the dorsal half of the constriction ring in one occasion, to improve the venous and lymphatic drainage, and the other half 12 weeks later. This procedure is also recommended in the literature, $1,8,10,11$

\section{CONCLUSÃO}

A Síndrome da Banda de Constrição Congênita é uma patologia rara, de ocorrência ocasional na natureza e sem comprometimento genético. É freqüente sua associação com amputações intrauterinas de dedos ou membros, sindactilia e acrossindactilia (sindactilia fenestrada). Pode haver envolvimento de tórax, abdômen e face. A assimetria das lesões é regra e envolvimento de membros inferiores pode estar presente. Os dedos mais afetados são II, III e IV, sendo o polegar freqüentemente poupado. Lesões profundas proximais ao punho podem causar lesão nervosa.

A indicação para abordagem cirúrgica é feita através da avaliação da criança e observação da presença de comprometimento neurológico, vascular ou linfático.

O tratamento nos casos em que há indicação cirúrgica, é baseado na liberação dos anéis constritivos através de zetaplastias, permitindo assim ganho em comprimento da pele e subcutâneo.

Deve-se ter em mente que procedimentos cirúrgicos outros podem ser necessários para corrigir deformidades associadas, principalmente sindactilia e acrossindactilia.
Fig. 10 - Cicatriz cirúrgica de zetaplastia usada para correção de anel de constrição congênita no antebraço.

\section{CONCLUSION}

The Congenital Constriction Band Syndrome is a rare pathological condition, of occasional occurrence in the nature and without genetic involvement. It is frequently associated with intrauterine amputations of fingers or limbs, syndactyly and acrosyndactyly (fenestrated syndactyly).

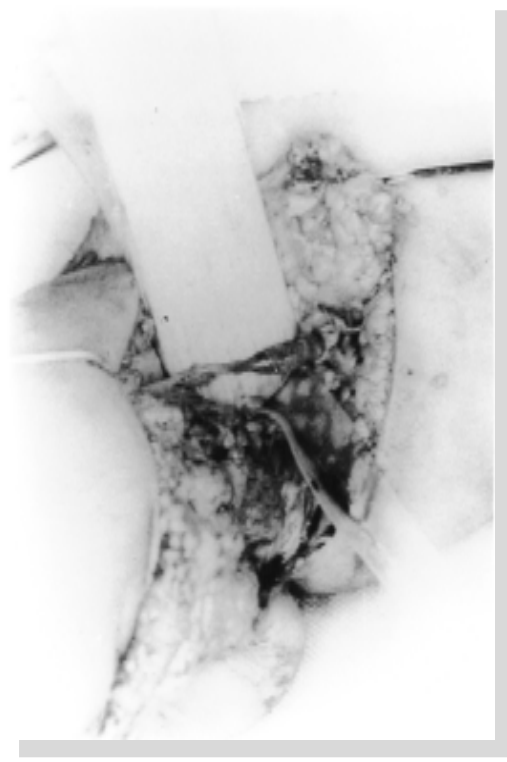

Fig. 11 - Neurotmese do nervo radial devido esmagamento causado por anel de constrição no terço distal do braço. Mesmo paciente da fig. 4. There can be involvement of the thorax, abdomen and face. Assymetry of the lesions is a rule and involvement of the lower limbs may occur. The fingers II, III and IV are the most affected; the thumb is generally spared. Deep lesions near the wrist can cause nerve lesions.

Indication to surgical approach is made after assessing the child and observing neurological, vascular or lymphatic involvements.

Treatment of the cases with surgical indication is based on the constrictive rings liberation through Zplasties, allowing improvement of the skin and subcutaneous tissue extension.

One must have in mind that other surgical procedures may be necessary to correct associated deformities, mainly syndactyly and acrosyndactyly. 


\section{REFERÊNCIA}

1. Askins, G.\& Error, G. Congenital constriction band syndome. J. Ped. Orthop. 8: 461-466, 1988.

2. Burgens, R.C.\& Lexington, K.: Brachydactyly in acrosyndactyly. J Hand Surg. (Am) 16: 125-126, 1991.

3. Kulkarni, M.L. \& Gopal, P.V.: Amniotic band syndrome. J. Indian Ac. Ped. 27: 471-476, 1990.

4. Levy, P.A.: Amniotic band. Pediatrics in Review 19: 249, 1998.

5. Muguti, G.I.: The amniotic band syndrome: Single-stage correction Brit. J. Plast. Surg. 43: 706-708, 1990.

6. Quintero, R.A., Morales, W.J., Kalter, C.S. et al: In utero lysis of amniotic bands. Ultrasound Obstet. Gynecol. 10: 316-320, 1997.

7. Uchida, Y. \& Sugioka, Y:: Peripheral nerve palsy associated with congenital constriction band syndrome. J. Hand Surg. (Br) 16: 109-112, 1991.

8. Upton, J. \& Tan, C.: Correction of constriction ring. J. Hand Surg (Am) 16: 947-953, 1991.

9. Visuthikosol, V. \& Hompuem, T.: Constriction band syndrome. An Plast. Surg. 21: 489-495, 1988.

10. Walter, J.H., Goss, L.R. \& Lazarra, A.T.: Amniotic band syndrome. J. Foot Ankle Surg. 37: 325-333, 1998.

11. Wiedrich, T.A.: Congenital constriction band syndrome. Hand Clin.14 - 1: 20-38, 1998. 